\title{
The Effect of Managerial Competence and Teacher Professional Competence on Academic Achievement of Primary Schools in Kecamatan Jeruklegi, Cilacap District
}

\author{
$1^{\text {stRetno Purwaningsih }}{ }^{1}, 2^{\text {nd }}$ Yahya Sudarya ${ }^{2}, 3^{\text {rd }}$ Etin Agustini ${ }^{3}, 4^{\text {th }}$ Widyanti $^{4}$ \\ \{ $\underline{\text { retnopurwaningsih160679@gmail.com }}^{1}$, yahyasudarya@ yahoo.com ${ }^{2}$, \\ e10.zahra@gmail.com ${ }^{3}$, widyanti02@gmail.com ${ }^{4}$ \}
}

SD Jeruk Legi Wetan 01, Jeruklegi, Cilacap ${ }^{1}$, Magister Pendidikan Dasar, Universitas Muhammadiyah Purwokerto, Jl KH Ahmad Dahlan, Banyumas 53182, Indonesia ${ }^{2}$, SD Negeri Gumilir 06, Cilacap Utara ${ }^{3}$, SD Negeri Gunung Simping 02, Cilacap Tengah ${ }^{4}$

\begin{abstract}
One of the competencies of school principals who play a role in school management is managerial competence. The purpose of this study was to determine the effect of principal managerial competence and teacher professional competence on elementary school academic achievement in Jeruklegi District, Cilacap. This research was conducted at elementary schools in Jeruklegi District, Cilacap Regency. There are 18 primary schools for data collection. This study used a survey model developed by Gay. The data collection used in this study were questionnaires, interviews and documentation methods. The effect of principal managerial competence on school achievement is not significant. The effect of teacher professional competence on school academic achievement is also not significant. The influence of managerial competence of school principals and professional teachers on academic achievement is very influential. So, it can be concluded that the principal managerial competence and professional teachers affect the achievement of academic achievement in elementary schools in Jeruklegi Cilacap.
\end{abstract}

Keywords: Managerial Competency, teacher Professional Competency, Academic Achievement. Elementary School

\section{Introduction}

Education in Indonesia has undergone a change in civilization which demands changes in all segments of life., included school management. This change requires changes and improvements in the competence of school principals and management. School principal has the following duties and functions: "The principal has the following duties and functions: as an educator, leader, manager, administrator, entrepreneur, creator of the working climate and supervisor [1]. Based on the explanation above, it can be concluded that the principal is a professional teacher who is trusted to lead the school and its elements to achieve the quality and objectives of education."

Hidayat and Ulya stated that the competencies that school principals must have to face the 21 st century are the dimensions of personal, managerial, entrepreneurial, supervised, and social competencies [2]. From these dimensions, one of the roles in school management is managerial 
competence. Managerial competence is the principal's ability to organize and develop school resources to create an effective and efficient learning environment. If managerial competence can be implemented very well, it certainly contributes well to school quality and achievement.

Teacher competence will greatly determine the quality of educational outcomes, because teachers are the party who has the most direct contact with students and the learning process in school educational institutions [3]. Then, Tobari et al. stated that the strategy carried out by the principal in order to improve the quality of education was to increase teacher competence. One of the competencies that teachers must have been professional competence [4]. Teacher professional competence is an ability or skill that must be possessed so that teacher assignments can be completed properly.

In terms of school output, it can be seen in terms of academic and non-academic achievements. According to Witherington, achievement is the result achieved by the individual through the effort experienced directly and is a skill activity in certain situations [5]. Meanwhile, academic achievement according to Bloom in Sudjana is the result of behavior change which includes cognitive, affective and psychomotor domains, which are measures of student success. In the eyes of the community, academic achievement is seen as representing the achievement of the peak performance of a school [6].

Researchers made observations at Elementary Schools (SD) in Jeruklegi District, Cilacap Regency. The following results obtained academic achievement tended to be achieved by certain schools only. The results of the observations of the researchers showed that the highest national examination scores in 2017, 2018 and 2019 were achieved by SD Negeri Jeruklegi Wetan 2, the results of the OSN competition at the Regency level in the last three years appeared at SD Negeri Karangkemiri 02 and for the LCC Contest in the last few years always appeared was SD Negeri Brebeg 01.

This study aims to describe (1) the effect of principal managerial competence on school academic achievement in Jeruklegi District, Cilacap Regency; (2) the influence of teacher professional competence on the quality of learning and school academic achievement in SD Jeruklegi District, Cilacap Regency; (3) the effect of principal managerial competence and teacher professional competence on school academic achievement in Jeruklegi District, Cilacap Regency.

\section{Method}

The research method that researchers use is survey research. Survey research is used to collect data or information about a large population using a relatively small sample. Survey models are most often used as research reports [7]. This research is divided into three stages of activities as follows the preparation stage, implementation stage and analysis stage. The population in this study were principals and teachers from various regions in Jeruklegi District, Cilacap Regency, namely principals with high, medium and low academic achievement performance.

The process of selecting individuals as samples is by using random samples. Selection of this sample every individual in the population has the same possibility of being selected. The most representative sample will allow the researcher to generalize to a population [8]. The number of principal respondent to be taken is 18 principals. In addition, the population of this study were teachers. The teachers we will sample are from various elementary schools in Jeruklegi District, Cilacap Regency. The number of teacher respondent is 36 teachers. 
The data collection used in this study were questionnaires, interviews and documentation methods. The questionnaire in the study was aimed at school principals and teachers to find out some competencies in the field of leadership and teacher professionalism and their relation to student achievement. The questionnaire was arranged using a Likert scale with intervals of 1 to 5. The number of questions compiled for the teacher professionalism questionnaire was 40 items. Meanwhile, the number of questions to determine the principal's managerial competence was 76 items.

Interviews were conducted to collect data about the principal's leadership competence (managerial competence) and teacher professional competence in achieving academic achievement. The documentation instrument used in this study is data on academic achievement of elementary schools in Jeruklegi District, Cilacap Regency such as OSN championship data and other competitions, championship trophies, award certificates and National Examination results data. School achievements also measured non academic achievement include the Mapsi, MTQ, LCC competitions, Student Achievements, Literacy, Literary Festival, OSN / KSN, Olympiad subjects, FLS2N, arts and culture championships, macapat, and Javanese speech. The data analysis technique used is multiple linear regression.

\section{Result and Discussion}

\subsection{Principal Managerial Competencies}

Consisting of 18 respondents, quantitatively, it shows the tendency that the minimum total score is 72 and the maximum score is 360 .The following are the results of the questionnaire regarding the managerial competence of school principals in this study described in table 1.

Table 1. Principal's Managerial Competence

\begin{tabular}{|c|c|c|c|c|}
\hline No & Interval & Criteria & Amount & Prosentase (\%) \\
\hline 1 & $308-365$ & Very high & 7 & 38.8 \\
\hline 2 & $250-307$ & High & 10 & 55.6 \\
\hline 3 & 192- 249 & Moderate & 1 & 5.6 \\
\hline 4 & 134- 191 & Low & - & 0 \\
\hline 5 & $76-133$ & Very low & - & 0 \\
\hline \multicolumn{3}{|c|}{ Total } & 18 & 100 \\
\hline
\end{tabular}

Based on table 1 above, it can be explained that most of the respondents have a high level of managerial competency criteria for school principals in Jeruklegi sub-district, Cilacap Regency.

\subsection{Teacher Professional Competence}

The results of a questionnaire on the professional competence of teachers in table 2 .

Table 2. Teacher Professional Competence

\begin{tabular}{ccccc}
\hline No & Interval & Criteria & Amount & Prosentase (\%) \\
\hline $\mathbf{1}$ & $156-180$ & Very high & 8 & 22.2 \\
$\mathbf{2}$ & $126-155$ & High & 24 & 66.7 \\
$\mathbf{3}$ & $96-125$ & Moderate & 4 & 11.1 \\
$\mathbf{4}$ & $66-95$ & Low & - & 0 \\
$\mathbf{5}$ & $36-65$ & Very low & - & 0 \\
\hline & TOTAL & & 36 & 100 \\
\hline
\end{tabular}


According to table 2, the professional competence of teachers in Jeruklegi sub-district, Cilacap district is predominantly in the high category.

\subsubsection{School Academic Achievements}

Achievements that fall into the academic category include the Mapsi, MTQ, LCC competitions, Student Achievements, Literacy, Literary Festival, OSN / KSN, Olympiad subjects, FLS2N, arts and culture championships, macapat, and Javanese speech.

From the results of data collection of sample school documents, it was found that 41 academic achievements. The number of academic achievements at the district level 35 , the district level 4, the provincial level 1 and the national level 1. The graph of the Academic Achievement Score Score for Primary Schools in Jeruklegi District is depicted in Figure 1 as follows:

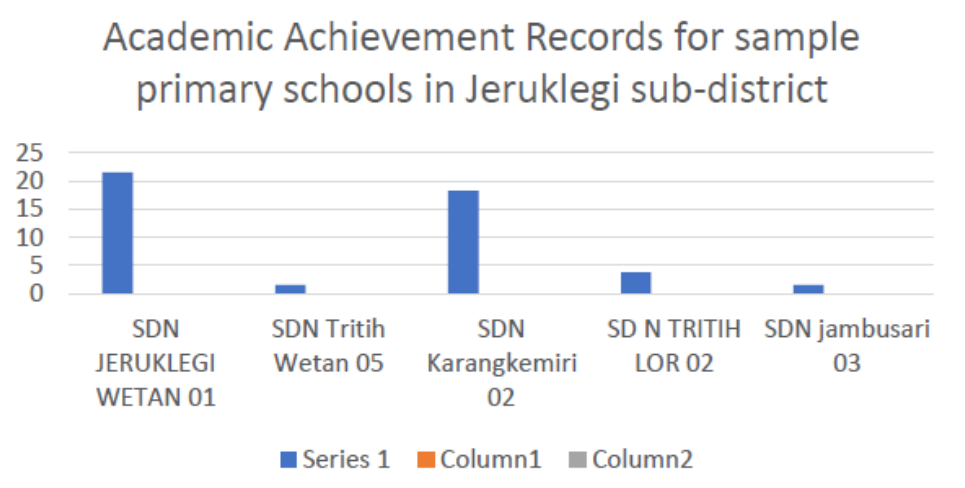

Figure 1. The graph of the Academic Achievement Score for Primary Schools in Jeruklegi District

Figure 1 have shown the primary school achievement records in Jeruklegi District. Based on it, can be seen that SDN Jeruklegi Wetan 1 has the highest academic achievement record in Jeruklegi District, Cilacap Regency.

To determine whether there is an effect between principal managerial competence and teacher professional competence on school academic achievement using multiple linear regression test with three prerequisite analysis tests, namely the normality and linearity test and the multicollinearity test.

\subsubsection{Analysis}

To measure the percentage of influence given by the professional competency variable (X1) and the principal managerial competence variable (X2) simultaneously (together) on academic achievement (Y). The following shows the results of multiple linear regression analysis (in the $\mathrm{F}$ test) in the following Table 3. 
Table 3. Results of Multiple Linear Regression Analysis

\begin{tabular}{llrrrrr}
\hline & Model & Sum of Squares & df & \multicolumn{1}{c}{$\begin{array}{c}\text { Mean } \\
\text { Square }\end{array}$} & F & Sig. \\
\hline 1 & Regression & 361.473 & 2 & 180.737 & 8.599 & $.003^{\text {a }}$ \\
& Residual & 315.277 & 15 & 21.018 & \\
Total & 676.750 & 17 & & & \\
\hline
\end{tabular}

a. Predictors: (Constant), Kompetensi Manajerial (X2), Kompetensi

Profesional(X1)

b. Dependent Variable: Prestasi Akademis (Y)

The findings of the data analysis presented above show that principal managerial competence and teacher professional competence have a simultaneous influence on academic achievement in elementary schools in Jeruklegi District, Cilacap. The significance level is $0.003<0.05$. These findings indicated that the principal's managerial competence and teachers' professional competence both have an impact on school academic achievement. This means that, when combined, managerial and professional competence of teachers will have an impact on school academic achievement.

The managerial ability of the principal can have an impact on teacher performance. The role of principal leadership in fostering teacher achievement motivation is critical. The principal has a large duty and responsibility as a manager in managing his school. The principal's success in managing his school is inextricably linked to the principal's ability as a school leader to carry out the functions and roles of school principal [4][9].

As a result, a school principal must be capable of managing the school; the readiness of the leadership referred to here is managerial ability [2][10]. With good managerial skills, it is hoped that each principal will be able to become a driving force and enforcer of discipline for teachers, allowing them to demonstrate productivity, good performance, and professional competence. Teachers are in charge of the main duties and the discipline in carrying out tasks. And, in the end, this ongoing relationship will produce a slew of accomplishments, particularly in the academic realm.

Based on the above description, this research is expected to help the principal improve good and appropriate managerial abilities. Then, through the principal's managerial abilities, it can contribute to professional competence. The managerial abilities of school principals and the professional performance of teachers, when combined, are related to school academic achievement. The simultaneous (joint) influence of the variables teacher professional competence (X1) and principal managerial competence (X2) affects the academic achievement variable (Y) by 53.4 percent. Other factors then influence 46.6 percent.

The findings of interviews with several school principals revealed that academic achievement was influenced by a variety of factors including personal students, parental support, the process of teacher development, and the school principal's good coordination. Some of the efforts made by school principals to improve academic achievement include: (1) coordination; (2) motivation, either verbal or written; and (3) reward for students or teachers who have achieved success. Whereas the following were some of the obstacles encountered as a result of several interviews with teachers in the process of achieving academic achievement: (1) Pandemic conditions have limited communication a little; (2) Students lack self-confidence; and (3) Infrastructure. 


\section{Conclusion}

The principal's managerial competence and teachers' professional competence both have an impact on school academic achievement. Then, the managerial ability of the principal can have an impact on teacher performance. With good managerial skills, it is hoped that each principal will be able to become a driving force and enforcer of discipline for teachers, allowing them to demonstrate productivity, good performance, and professional competence.

\section{References}

[1] Mulyasa. Menjadi Kepala Sekolah Profesional. Bandung: PT Remaja Rosda Karya. (2011).

[2] Hidayat R, Ulya H. Kompetensi kepala sekolah abad 21: Sebuah tinjauan teoretis. Jurnal Kepemimpinan dan Pengurusan Sekolah. 2019 Mar 30;4(1):61-8.

[3] Josanov-Vrgovic I, Pavlovic N. RELATIONSHIP BETWEEN THE SCHOOL PRINCIPAL LEADERSHIP STYLE AND TEACHERS'JOB SATISFACTION IN SERBIA. Montenegrin Journal of Economics. 2014;10(1):43.

[4] Tobari T, Kristiawan M, Asvio N. The Strategy of Headmaster on Upgrading Educational Quality in Asean Economic Community (AEC) Era. International Journal of Scientific dan Technology Research. 2018;7:72-9.

[5] Witherington C. Psikologi Pendidikan. Jakarta: Rineka Cipta. 2003.

[6] Sudjana N. Metoda Statistika. Bandung: Tarsito. 2009.

[7] Gay LJ. Educational Research: Competences Analysis and Application. Columbus: Merill Publishing Company. 1987.

[8] Creswell JW. Research Design. Yogyakarta: Pustaka Pelajar. 2020.

[9] Badarudin B. Peran Kepala Sekolah Dasar dalam Mempersiapkan Sumber Daya Pendidik Menghadapi Implementasi Kurikulum 2013. Dinamika Jurnal Ilmiah Pendidikan Dasar. 2019 Feb 12;10(2).

[10] Khusni W, Mahmudah FN. THe principal's managerial ability in developing effective schools. International Journal of Educational Management and Innovation. 2020 Mar 9;1(2):99-108.

[11] Wibowo WD, Wakhudin W. The Roles of Leadership Principal to Improving of Education Quality through Managerial Competence. Dinamika Jurnal Ilmiah Pendidikan Dasar. 2021 Sep 22;13(2):79-82.

[11] Muslim AH, Harmianto S. The Leadership Style of Muhammadiyah Elementary School Headmasters. Dinamika Jurnal Ilmiah Pendidikan Dasar. 2020 Apr 5;12(1):55-66. 